УдК 339.1-330.3

A. Kvitka, Doctor of Philosopby in Economics, associate professor, Deputy Director of the Educational and Scientific Institute "Karazin Business School", V. N. Karazin National University, Kbarkiv ORCID ID: 0000-0002-5730-1352

A. Kramarenko,

Doctor of Pbilosopby in Economics, senior lecturer of the Department of Management and Administration of the Educational and Scientific Institute "Karazin Business Scbool", V. N. Karazin National University, Kharkiv ORCID ID: 0000-0001-5987-1247

DOI: $10.32702 / 2306-6814.2020 .1 .64$

\title{
ENTREPRENEURSHIP IN THE SHARING ECONOMY: SOCIAL BENEFITS AND DIGITAL GROWTH
}

\author{
А. В. Квітка, \\ к. е. н., доцент, заступник директора ННІ "Каразінська школа бізнесу", \\ Харківський національний університет імені В. Н. Каразіна, м. Харків \\ А. О. Крамаренко, \\ к. е. н., старший викладач кафедри управління та адміністрування ННI "Каразінська школа бізнесу", \\ Харківський національний університет імені В.Н. Каразіна, м. Харків
}

\section{ПІАПРИЄМНИЦТВО В ЕКОНОМІЦІ ОБМІНУ: СОЦІАЦЬНІ ВИГОАИ ТА ЦИФРОВЕ ЗРОСТАННЯ}

The directions of development of small and medium-sized enterprises in the framework of the exchange economy and the circular economy, as well as issues related to promising areas of entrepreneurial innovation and the growth of digital business are considered. It is shown that the key sectors for innovation are food industry, packaging, water supply and clothing production. Changes in modern business models, which are the switching of the representatives of small and medium-sized businesses to the implementation of the main postulates of the circular economy, namely, to reduce consumption and reuse of natural resources, are studied. Modern market strategies and small and medium-sized enterprises trying to implement them are analyzed. It was concluded that the creation of innovative enterprises within the sharing economy not only contributes to the improvement of the economic situation, but also creates additional social effects. It is shown that the main focus of retailers is loyalty and customer retention, rather than selling more units of the product. The strengthening of the transformation of supply chains in the areas of cooperation between trading platforms and large consumer goods firms, integration of artificial intelligence and machine learning, and integration of social networks are emphasized. It is revealed that startups and newcomers to the market place goal and influence at the centre of their brands, because the impact brands are growing much faster than others. It is shown that the values necessary for creating the image of a "virtuous brand" are "careful knowledge", "caring habits" and "caring imagination". It was concluded that along with increasing social responsibility and greening of business, business activity within the sharing economy has unexpectedly developed rapidly. It was emphasized that the use of the sharing economy has contributed to solving the problems of rational use of natural resources, effective employment and current problems of residents of large cities. Special attention is paid to fundamental changes in the landscape for entrepreneurs, which are manifested in the creation of effective ways of production while reducing internal costs, greater opportunities to enter the market, increased competition, the transition of power from large corporations to innovative enterprises.

Досліджено напрями розвитку малих і середніх підприємств у рамках економіки обміну і кругової економіки, а також питання, пов'язані з перспективними напрямами підприємницьких інновацій і зростаннямдіджиталізації бізнесу. Показано, що ключовими секторами для інноваційє сфери харчової промисловості, пакування, водопостачання та виробництва одягу. Було вивчено зміни сучасних бізнес-моделей, які полягають у тому, що представники малого і середнього бізнесу поступово переключаються на реалізацію основних постулатів кругової економіки, а саме на скорочення споживання і на повторне використання природних ресурсів. Проаналізовано сучасні ринкові стратегії, що намагаються реалізувати малі та середні підприємства. Було зроблено висновок, що створення інноваційних підприємств у рамках економіки обміну не тільки сприяє оздоровленню економічної кон'юнктури, але й створює додаткові соціальні ефекти. Показано, що основним фокусом рітейлерів стають лояльність і утримання клієнтів, а не продаж більшої кількості одиниць продукту. 
Підкреслено посилення трансформації ланцюжків поставок у напрямах співпраці торгових майданчиків і великих фірм споживчих товарів, інтеграції штучного інтелекту і машинного навчання, інтеграції соціальних мереж. Виявлено, що стартапи і новачки ринку ставлять у центр своїх брендів мету і вплив, томущо бренди впливу ростуть набагато швидше, ніж інші. Показано, що цінностями, необхідними для створення іміджу "доброчесного бренду" $\epsilon$ "дбайливе знання", "турботливі звички" та "турботлива уява". Було зроблено висновок, що поряд з підвищенням соціальної відповідальності та екологізації бізнесу несподівано стрімкий розвиток отримала підприємницька діяльність у рамках економіки обміну. Підкреслено, що використання можливостей економіки обміну сприяло вирішенню проблем раціонального використання природних ресурсів, ефективного працевлаштування і актуальних проблем жителів великих міст. Особливу увагу приділено корінним змінам ландшафту для підприємців, що проявляються у створенні ефективних способів виробництва за одночасного зниження внутрішніх витрат, більших можливостях для виходу на ринок, посиленні конкуренції, переході влади від великих корпорацій до інноваційних підприємств.

Key words: digital transformation, circular economy, social entrepreneurship, supply chains.

Ключові слова: иифрові перетъорення, кругова економіка, соціальне підприємництво, ланцюжки постаВок.

\section{INTRODUCTION}

According to recent scientific publications, we're steadily moving to the concept of shared value from the periphery to the core of businesses, connecting company success with social progress. Most entrepreneurs are now aware of the growth and need for purpose-driven companies. They are a response to consumer demand, as buyers seek out brands that help them make a positive impact in the world [1]. Thus, in modern conditions, the demand for socially oriented business is rapidly increasing. This trend is most evident in the sharing economy. The consumer P2P rental market is believed to be worth US $\$ 26$ billion today, and even more so, the revenue of sharing economy companies are expected to grow from a $\$ 15$ billion in 2015 to $\$ 335$ billion in 2025 [2]. In this regard, the issues of factors of development of the sharing economy, as well as the relationship of changing business models and the implementation of programs of the circular economy reveal.

\section{LITERATURE REVIEW}

Recently, the investment consulting firm Cornerstone Capital Group, published a report on the circular economy, which analyzed the impact on pollution in various areas of activity [3]. However, in the light of this analysis, it would be interesting to examine the relationship between circular economy and sharing economy. The sharing economy is inherently changing the future of work, production, and collaboration, and on a personal level, changing our concept of ownership and our attachment to it [2]. In this regard, research aimed at studying promising areas of business innovation and changes in modern business models is becoming relevant.

\section{PURPOSE OF ARTICLE}

The purpose of this article is to study the directions of development of small and medium-sized enterprises in the sharing economy and the circular economy, as well as issues related to promising areas of entrepreneurial innovation and the growth of business digitalization.

\section{RESULTS}

In the published report of Cornerstone Capital Group:

- critical resource problems are identified;

- examples of companies implementing circular economy practices in supply chain management are given;
- new business models and examples of cooperation supporting the principles of circular economy are considered [3].

According to the report, key sectors for innovation include:

- apparel (less than 1\% of material used to produce clothing is recycled into new clothing, with much of the waste winding up in landfills)

- food (each year, 52.4 million tons of food is sent to landfills, and an additional 10.1 million tons remains unharvested at farms, totaling roughly 63 million tons of annual waste)

- consumer packaged goods, as well as packaging for food, ecommerce and so on (in 2015, roughly $55 \%$ of global plastic waste was discarded, $25 \%$ incinerated and $20 \%$ recycled)

- water sector (since so many manufacturing processes result in wastewater and pollution) [3].

In light of the above, we can assume that more and more entrepreneurs are aware of the need to change the current business model. Representatives of small and medium-sized businesses are gradually switching to the implementation of the main postulates of the circular economy, namely, to reduce consumption and reuse precious natural resources. These strategies are being implemented by various companies representing different sectors of the economy, in particular:

1. Recyclops

Problem: there are 34 million single-family homes throughout rural regions and smaller communities and 16 million apartments that lack recycling [4].

Solution: service that leverages a tech-driven smart routing app and local drivers

Methods: providing curbside recycling in rural areas, doorstep recycling for urban apartments, curbside recycling for businesses.

Social benefits: elimination many of the logistical problems.

2. Scrappy Pet Treats

Problem: in the US, eggshells are listed as one of the top 15 food waste problems by the Environmental Protection Agency.

Solution: recycling eggshells from the food service industry waste stream and turns this high-value calcium source into pet treats. 
Social benefits:

- alleviation environmental degradation caused by the demand for mined calcium, which is taken from limestone mountaintops and coral reefs;

- human bodies actually absorb this organic source of calcium more efficiently than mined calcium carbonate [4].

3.1. FLI Right

Problem: only $9 \%$ of plastic waste is recycled.

Solution - FLI T3 System, which takes direct aim at plastic waste by empowering individuals and businesses to transform remnants into useful products [4].

Social benefits: potential revenue streams.

3.2. rePurpose

Problem: 8 million tons of plastic finds its way into our oceans every year; the enormity and impersonal nature of the statistics can lead to apathy and inaction.

Solution: strengthen the waste management infrastructure.

Methods: helping individuals and organizations measure their plastic footprint.

Social benefits: taking the responsibility for plastic by funding the recovery and recycling of an equivalent volume of plastic by vetted formal waste management enterprises [4].

4. Patagonia

Methods: makes $69 \%$ of its clothes from recycled materials (hoping to achieve $100 \%$ by 2025) [5].

Social benefits: doing good work for the environment helps create new markets, and it helps the company make more money.

\section{Stuffstr}

Problem: most clothes end up in landfill.

Solution: data-based solution that collects unwanted apparel and accessories from consumers (in any condition) and feeds it into either the second-hand clothing market or into material recycling streams.

Methods: working with clothing brands to pull data on all the products in their inventory into their platform, so that when a consumer no longer wants the item, they can search for it and instantly see what the company will pay to buy that item back. Stuffstr then collects the item from the consumer, take it to their sorting facility and put it into second-hand sales or recycling, depending on the quality of the item [6].

Social benefits: data on the items returned and the condition they are in feeds back to the brands. This can inform about:

- the brand's future product development

- customer product preferences

— length of time certain products are typically in use [6]

Thus, the creation of innovative enterprises within the exchange economy not only contributes to the improvement of the economic situation, but also creates additional social effects. The long-term impact is reflected in the transformation of supply chains. Where once the supply chain was linear and ended with the consumer or, more realistically, in a landfill or in the ocean tomorrow's supply chain will be circular, designed to encourage greater reduction, reuse, and repurposing through secondary, sustainable business models. The problem of the impact of the business environment on the environment is sharply aggravated in modern conditions, which contributes to the strengthening of sustainability trends in business. The main focus of retailers is loyalty and customer retention, rather than selling more units of the product. In this regard supply chains are being transformed in the following ways [7]:

1. Collaboration between marketplaces and large consumer goods firms (trading platform Loop created a partnership between P\&G, Unilever and Nestle and recycling firm TerraCycle. Loop will allow shoppers to consume products in reusable packaging).

2. Integration of artificial intelligence and machine learning:

- connecting physical technologies such as smart sensors and cameras to internal systems will provide "guaranteed" transparency, making the origin and ethical operations visible in real time;

- machine learning increases the accuracy of demand, which makes supply more efficient, reducing unnecessary production and therefore waste.

3. Social media integration:

— informing consumers about new ways to reduce and reuse;

- encourage them to participate in sustainability initiatives.

In addition, the emergence of the $\mathrm{EU}$ ban on singleuse plastics provides fertile ground for businesses to rethink their strategy by building a "virtuous brand". The values essential to "virtuous brand" image are:

- "caring knowledge" (taking action on the environment internally using recycled materials, exceeding legal compliance obligations, acting as a recycling center for plastic packaging and championing charitable causes that resonate with customers);

- "caring habits" (consistently contributing to the sustainable health and well-being of its customers through chemical-free, vegetarian product development, adopting green transport policies);

- "caring imagination" (influencing customers' behavior to adopt environmentally conscious lifestyles) [8].

That is why startups and market newcomers are at the forefront putting purpose and impact at the core of their brands, because impact brands are growing far faster than the rest, which explains why legacy brands have been purchasing these companies faster than ever [1]. For example, if an economy consisting of 50 cars retained by 50 owners suddenly switches to a sharing system of only 10 cars for 50 individuals (since cars are typically idle 80plus percent of the time), our economy would contract by 80 percent. Creating efficiency, in this case, to support a goal of homeostasis with our planet and improving human health, is not rewarded in a system driven by private consumption [1]. In this regard, along with increasing social responsibility and greening of business, business activity within the sharing economy has unexpectedly developed rapidly. While the sharing economy has been widely used in the past two years, it's an economic term that has existed since 2010. Many scholars and thinkers have tried to define it in different ways, from a socioeconomic ecosystem to collaborative consumption, we found the most recurring ones to be:

- the recirculation of goods (e.g. eBay or Craigslist);

- the exchange of services (TaskRabbit with 2 million users in 19 cities); 
- the utilization of underused assets (AirBnb, who had over two million listings in 190 countries, and was valued at $\$ 30$ billion; Uber, which is available in 76 countries, and valued at $\$ 68$ billion) [2].

And if the numbers are not characteristic enough, the sharing "concept" has now become engrained in people's psyche. Indeed, $75 \%$ of people believe nowadays that they will increase their sharing of physical objects and spaces in the next five years. We have also seen a new trend and spike in the number of freelancers; those of who have started using sharing economy "platforms" have seen their income rise from $10 \%$ in 2014 to $20 \%$ in 2015 [2].

The sharing economy model is a structure which amalgamates mindsets to pave way for individualism leading to a positive domino effect:

1. Efficient utilization of resources and digital growth. The growth of the sharing economy fundamentally changes the landscape for entrepreneurs in three primary areas:

- Distribution of production. While handling all aspects of a business in-house increases control, it does so at the expense of efficiency. Breaking up production processes into narrow tasks and outsourcing them to resource owners provides a simple, effective method of production while reducing in-house costs;

- Lower barriers to entry. As more people find opportunities to enter the market, competition increases while the power shifts from big corporations to innovative businesses. As a result, what matters most will not be who owns resources but who makes the most out of them;

- Less ownership, more maintenance. The sharing economy replaces passive ownership with active maintenance service. The owner of the idle resource, rarely the business itself, bears the brunt of the upfront cost. In a true sharing economy, owners compete for users. Holding idle resources becomes akin to luxury consumption since the owner foregoes income [9].

2. Splurge in job opportunities:

- growth in hassle-free jobs that come with the ease of avoiding confrontation with bosses and hounding HR for payment clearance;

- a laissez-faire employment structure wherein people can work according to their customized schedule

- working according to specific set of skills [10].

3. Urban solutions to millennial problems. The job opportunities/educational offers of ten require millennial to move base and in turn go to other cities [10]. A significant problem that brands and retailers face is Gen Z's propensity to buy based on lifestyle choices rather than loyalty to specific brands.

\section{CONCLUSIONS}

Within the framework of the study, various aspects of the mutual influence of small and medium-sized business development, trends of greening, socialization and digitalization of business activity were considered. According to the results of the study, the following conclusions can be drawn:

1. Business initiatives implemented within the circular economy provide significant social benefits, such as solving environmental and logistical problems, creating new business areas, and optimizing market supply.

2. Rethinking existing business models has shifted the focus of retailers and manufacturers towards enhancing digital collaboration, as well as integrating social networks and artificial intelligence.

3. Using the opportunities of the sharing economy contributed to solving the problems of rational use of natural resources, effective employment and current problems of residents of large cities.

\section{DISCUSSION}

In the development of the provisions of this study, it makes sense to pay special attention to the impact of mental characteristics of the Millennials generation on the pace of development of the sharing economy and the circular economy.

References:

1. Garn, R. (2019), "Conscious Capitalism: Are You Driven By More Than Just Money?" available at: https:// www.entrepreneur.com/article/338428 (Accessed 29 December 2019).

2. Infographic.Ly Team (2017) "Infographic: The Sharing Economy", available at: https://www.entrepreneur.com/article/295148 (Accessed 29 December 2019).

3. Cornerstone (2019), "Intentional Design: Embracing the Circular Economy", available at: https://cornerstonecapinc.com/wp-content/uploads/IntentionalDesign_Embracing-the-Circular-Economy.pdf (Accessed 29 December 2019).

4. Fox, M. M. (2019), "4 Environmental Startups Driving The Circular Economy", available at: https://www.forbes.com/sites/meimeifox/2019/12/06/4-environmental-startups-driving-the-circular-economy / \#6418dc80c864 (Accessed 29 December 2019).

5. Barr, S. (2019), "The Future Of Black Friday", available at: https://www.forbes.com/sites/stevenbarr $/ 2019 / 11 / 20 /$ the-future-of-black-friday/\#7999a92e21b2 (Accessed 29 December 2019).

6. Roberts-Islam, B. (2019), "The App Buying Back Your Unwanted Clothes To Fuel The Circular Economy", available at: https://www.forbes.com/sites/brookerobertsislam /2019/12/16/the-app-buying-back-yourunwanted-clothes-to-fuel-the-circular-economy / \#5108d19622e4 (Accessed 29 December 2019).

7. Hackenberg J. (2019), "How Circular Supply Chains Will Take Businesses From Landfill To Refill", available at: https://www.forbes.com/sites/jonquilhackenberg/ $2019 / 12 / 19 /$ how-circular-supply-chains-will-takebusinesses-from-landfill-to-refill / \#769a0b72f754 (Accessed 29 December 2019).

8. Young, S. and James, L. (2019), "The EU's New Environmental Initiatives Present Opportunities for Brands", available at: https://www.entrepreneur.com/ article /323386 (Accessed 29 December 2019).

9. Bylund, P. (2016), "3 Ways the Sharing Economy Changes Entrepreneurial Opportunity", available at: https://www.entrepreneur.com/article/254725 (Accessed 29 December 2019).

10. Saini, A. (2019), "Recommerce - Trending Business Solutions to Sustainability", available at: https:/ /www.entrepreneur.com/article/337259 (Accessed 29 December 2019).

Стаття надійшла до редакцї 29.12.2019 р. 